\title{
PEOPLE WITH VULNERABILITIES TO CYCLONE IN THE COASTAL AREA OF BANGLADESH: AN OVERVIEW
}

\author{
Abdul Karim Gazi ${ }^{1}$ \\ ${ }^{1}$ Studying BSS in Sociology, University of Barishal, Barishal 8200, Bangladesh
}

\begin{abstract}
Purpose of the study: Cyclone is a common disaster in Bangladesh because of affecting the coastal area almost every year. This paper intends to explore the vulnerability to the cyclone and the possible way of mitigating the vulnerability in the coastal area of Bangladesh.

Methodology: This study is a content analysis of qualitative research and has been conducted based on secondary data collected through content analysis and historical method of data collection based on title and objectives.

Main findings: Only socio-economic factors aren't responsible for making, and rising vulnerability in coastal areas, rather physical, environmental, geographical setting, and cultural factors are responsible. Besides, after the cyclone, there are various problems to take proper steps, the author has discussed a process of emergency action after the cyclone and argued that the collaboration between government and NGOs could mitigate the vulnerability.

Applications of the study: This study is useful for them who want to know about vulnerability to cyclone in the coastal area of Bangladesh and the Governmental and Non-governmental organizations.

Originality of the study: The author has concluded that this study will help to take the step to reduce vulnerability to the cyclone and to whom who would like to help vulnerable people of the coastal area of Bangladesh and study on vulnerability.
\end{abstract}

Keywords: Bangladesh, Cyclone, Vulnerability, Vulnerability Mitigation,

\section{INTRODUCTION}

First of all, Bangladesh is the $6^{\text {th }}$ most disaster-prone countries in the world in which 97.7 percent of the total population and 97.1 percent of total areas are at risk and threatened by climate change, including- sea level rising, storm surge, coastal cyclone, etc. (Hussain \& Rahman, 2018; Goosen et al., 2018). It is clear that to maintain economic growth and alleviate poverty, Bangladesh has to reduce the vulnerability of cyclone instantly (Goosen et al., 2018). But, some factors, including- economic, social, physical, or geographic nature, reduce to cope with the impact of the cyclone and are root causes of vulnerability. Last, of all, the Bangladesh government has to take those factors into account so that the vulnerable and deplorable situation can be eradicated severely.

The overarching goal of the study is to build information on vulnerability to cyclone in the context of Bangladesh, but specific objectives are-

1. To define vulnerability and cyclone,

2. To analysis types of vulnerability,

3. To examine the causes of vulnerability,

4. To analyze the mitigation process of vulnerability.

\section{LITERATURE REVIEW}

\subsection{Concept of Cyclone}

Cyclone, derived from "Kyklos" (coil of snakes), occurs in the Indian Ocean area. It occurs in early summer (AprilMay) or late rainy season (October-November). Cyclone originates from low atmospheric pressure over the Bay of Bengal (Khan, 1992; Rahman et al., 2018). Cyclones in South Asian Sub-Continent are presently classified according to their intensity, and the following nomenclature is in use:

Corresponding Author: ${ }^{1}$ gazikarimbu@gmail.com 
Table 1: Measurement of the cyclone.

\begin{tabular}{ll}
\hline Category & Wind speed \\
\hline Depression & winds up to $62 \mathrm{~km} / \mathrm{h}$ \\
Cyclonic storm & winds up from $63-87 \mathrm{~km} / \mathrm{h}$ \\
Severe cyclone & winds from $88-118 \mathrm{~km} / \mathrm{h}$ \\
Severe cyclonic storm of Hurricane intensity winds & above $118 \mathrm{~km} / \mathrm{h}$ \\
\hline
\end{tabular}

Source: Khan (1992)

Among these four types of wind speed, $88-118 \mathrm{~km} / \mathrm{h}$ speed appears as usual. This speedy wind damages the coastal area of Bangladesh. The speed of wind above $188 \mathrm{~km} / \mathrm{h}$ occasionally appears in Bangladesh. The speed of wind below $60 \mathrm{~km} / \mathrm{h}$ often occurs and damages less than other types of cyclones.

The coastal area of Bangladesh is 47,211 square $\mathrm{km}$, and 35 million people live there. Warnings are issued by the metrological department using a system for warning shipping of an impending cyclone. The information on cyclones is collected from international satellite images. The warning system uses a scale from 1 to 11 for the seaports and 1 to 4 for river ports (Shamsuddoha \& Chowdhury, 2007). The standing Orders for Cyclone (SOC) guides over warning stages:

Table 2: The signal of cyclone

\begin{tabular}{ll}
\hline Situation & Signal \\
\hline Pre-disaster stage & off-cyclone season \\
Alert stage & signal No. I, II, and III \\
Warning stage & signal No. IV \\
Disaster stage & signal NO. V, VI, VII, VIII, IX and X \\
The post-disaster stage & immediately after the cyclone till normalcy is attained \\
\hline
\end{tabular}

Source: Miyan (2005)

However, signal $\mathrm{X}$ is the main type of signal which indicates the more risk to vulnerable groups. All signals of under $\mathrm{X}$ are more important until IV. From I to III, these signals often appear, but the amount of damage may be lower than above IV.

The truth is that Bangladesh has achieved experiences to observe a lot of devastating cyclones. A report, conducted in 2017 has shown 12 major cyclones of Bangladesh which suggested that cyclone damages quite sharply, like-

Table 3: 12 major cyclones in Bangladesh

\begin{tabular}{ll}
\hline Date of cyclone & Amount of deaths \\
\hline May 11, 1965 & 19279 \\
December 1965 & 873 \\
October 1966 & 850 \\
November 11, 1970 & 300,000 \\
May, 1985 & 11,069 \\
November 30, 1988 & 5708 \\
April, 1991 & 138,000 \\
May 1997 & 155 \\
November 15, 2007 & 3363 \\
May 25, 2009 & 150 \\
May 16, 2013 & 17 \\
May 21, 2016 & 26 \\
\hline
\end{tabular}

Source: Ahmed (2017)

The cyclones as mentioned above, are a more mentionable cyclone of Bangladesh which is responsible for damaging the economy of Bangladesh. In fact, every cyclone kills a lot of people and damages the property of this developing Bangladesh.

While that is unacceptable, what is cyclone affects not only Bangladesh but also the world deadly. UN member states adopted the Sendai Framework for Disaster Risk Reduction 2015-30 to reduce the loss of disaster, because the disaster disrupts the way of poverty reduction and the main goal of Sustainable Development Goal (SDG) from all 
over the world, especially in low income and middle-income countries (Wailemacq \& McClear, 2017). From 19982017 , the world has been affected by various disasters, cyclone or storm is mentionable, like-

Table 4: Disasters and their effects in the world

\begin{tabular}{|c|c|c|c|c|}
\hline Name of Disasters & $\begin{array}{l}\text { Numbers of } \\
\text { disasters }\end{array}$ & Economic losses (\$) & $\begin{array}{l}\text { Number of affected } \\
\text { people }\end{array}$ & $\begin{array}{l}\text { Number } \\
\text { deaths }\end{array}$ \\
\hline Storm & 2,049 & 1330 billion & 725 million & 232,680 \\
\hline Earthquake & 563 & 661 billion & 125 million & 747,234 \\
\hline Flood & 3148 & 656 billion & 2.0 billion & 142,088 \\
\hline Drought & 347 & 124 billion & 1.5 billion & 21,563 \\
\hline Extreme temperature & 405 & 61 billion & 97 million & 166,346 \\
\hline
\end{tabular}

Source: Wailemacq \& McClear (2017)

This table is showing that along with other disasters, the cyclone has a role in damaging the balanced world and kills a lot of people who are the main creature of the world. It is clear that without taking proper steps, people won't be able to make a better place for living.

\subsection{Concept of Vulnerability}

Vulnerability is also human dimension of disasters and result of the range of economic, social, cultural, institutional, political and psychological factors, including- social group, age, gender, design, and construction of buildings, inadequate protection of assets, lack of public information and awareness, limited official recognition of risk, and preparedness which make people isolated, insecure and defenseless in the face of risk (PreventionWeb, 2015; ODPM, 2013; IFRCRCS, 2019).

At the same time, to discuss vulnerability, we have to know the process of vulnerability. 'Pressure And Release (PAR) model: the progress of vulnerability' is a process of making vulnerability which has shown how the vulnerability is created to disaster. Although this approach has contained a lot of disasters, the cyclone is one of them.

Figure 1: Pressure and Release (PAR) model: the progress of vulnerability

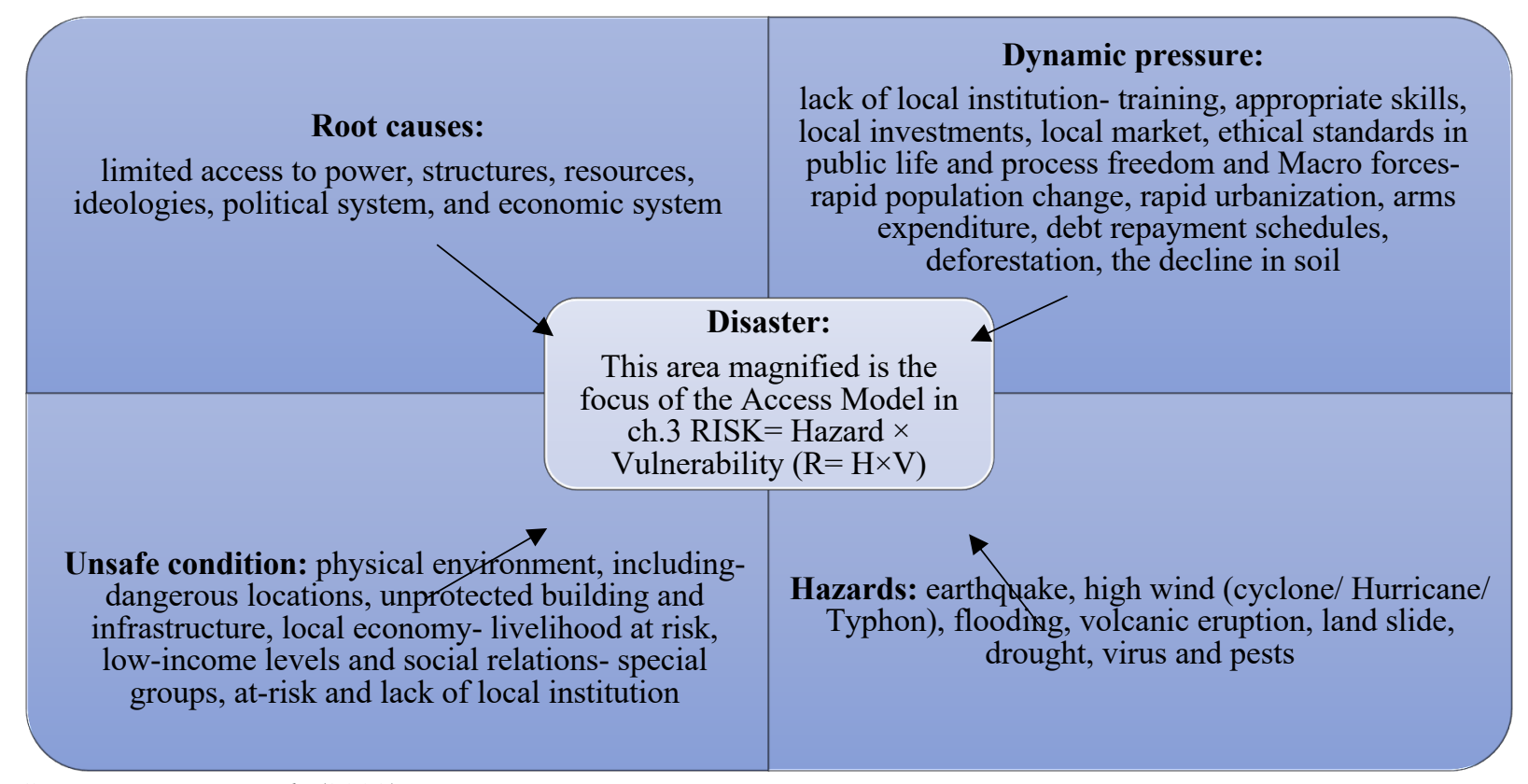

Sources: Wisner et al. (2003)

The root causes, dynamic pressure, and unsafe condition are vulnerability, which makes risk with the help of hazards. Those people are secure who are free from the above conditions. So, eradicating the above factors must be needed to reduce the intensity of vulnerability.

\subsection{Cyclone and Vulnerability}


Disaster is the product of natural hazards on vulnerable people who are living in disaster-prone areas (Cannon, 2008). vulnerability is a set of socio-economic conditions, including- livelihood, baseline status, self-protection, and social protection that is identifiable and related to particular hazard risk and can be removed by the political and economic process (Cannon, 2008). Bangladesh is situated at a vulnerable location because of geographical and geomorphological conditions. Among all inhabitants of coastal areas, women are more affected by disasters because they depend on local natural resources and have limited decision-making power and access to resources (Sharmin \& Islam, 2013). Poverty rises vulnerability during the disaster in the coastal areas of Bangladesh. To reduce vulnerability, the dwellers have to make disaster resilience building which will be possible when poverty can be removed from those affected people (Chaudhury, 2017). Without poverty, several phenomena rise vulnerability, such as- unplanned settlements, dependency on dangerous and problematic places which are far away from cyclone shelters and transportations. Most of the people in those areas increase religious activities to satisfy their God. Some people can't go to cyclone shelters and take shelter in the thatched-roof house and big branches trees, and women and children are more affected by cyclone (Alam \& Collins, 2010). On the other hand, vulnerability can be reduced through three ways, such as- forecasting and warning, community preparedness, and land use planning (Bisson, 2012).

The author has wanted to study on vulnerability to the cyclone because cyclone is the top disaster of Bangladesh. Different scholars have argued on vulnerability to cyclones from different perspectives. Someone has focused on a gender perspective, and another has focused on geographical, economic and other factors to make vulnerability to cyclone in the context of Bangladesh. No scholars focus on all factors of creating vulnerability to the cyclone and argued clear causes of vulnerability. So, the author has focused on all factors of creating vulnerability to cyclone in Bangladesh and tried to present clear causes of vulnerability.

\section{METHODS AND MATERIALS}

By focusing on the exact definition of cyclone and vulnerability, previous and current data on vulnerability to the cyclone, process of vulnerability and mitigation of vulnerability, the author started this study on vulnerability to cyclone in Bangladesh's perspective. This study is qualitative research in nature, finding out descriptive findings according to title and objectives which has completed based on content analysis methodology in which secondary data sources are information. Content analysis and historical methods have been used as the method of data collection. Those are secondary data which have been collected by researchers, academicians, organizations, etc. and other researchers use those data because of limited time and resources. Content analysis is a method of social research that analyzes the content of texts, pictures, films, and other forms. The historical method is employed as a method of data collection to depict the condition of vulnerability to the cyclone. Moreover, data have been collected from secondary data sources based on vulnerability to cyclones in the coastal area of Bangladesh.

Data are collected from books, articles, journals, archival records, reports, newspapers, internet websites, etc. which are only relevant to vulnerability to the cyclone, causes and mitigation of vulnerability to the cyclone. The author has defined the vulnerability and cyclone and discussed the whole paper on the vulnerable situation of coastal dwellers in his words based on scholars' arguments. Even a process named Emergency Action Plan Process formulated based on the fire in the USA to take action immediately after the fire has been discussed to take immediate actions after the cyclone in Bangladesh because the situation of after cyclone and fire are often the same.

Alexander (1993) developed six approaches to discuss the disaster, including- geographical, anthropological, development studies, disaster medicine, technical, and sociological approaches (Wisner et al., 2003). This study has used a sociological approach to discuss the vulnerable situation to cyclone in Bangladesh. The Sociological approach to disaster focuses on human condition, activities, and the effect of the disaster on human beings and society. So, this study has discussed human activities, vulnerable situations, and the effect of the cyclone on society.

\section{RESULTS AND DISCUSSION}

Bangladesh is ranked $15^{\text {th }}$ according to total damage as a percentage of GDP, $2^{\text {nd }}$ according to the population affected, and $23^{\text {rd }}$ according to the total number of disasters relative to the landmass. It is a simple matter that natural hazards have short-or long-term consequences on economic growth and poverty. Long term changes in vulnerability, structure, and composition of economic activity prove the development of any country. Vulnerability to disaster is determined by a complex, dynamic set of influences, such as economic structure, stage of development and prevailing economic and policy conditions (Benson \& Clay, 2003). 


\subsection{Results of the Study}

In the first place, disasters are not only natural events but also the product of society, politics, economy, and environment. Indeed, natural hazards direct hit on life and property, but several factors make people vulnerable. The vulnerability is generated by a social, economic and political process that raises the intensity of damage (Wisner et al., 2003). Scholars and organizations have identified several types of vulnerability to cyclone all over the world. The author has used those types of vulnerabilities to cyclone in Bangladesh's perspective because all types of vulnerability to cyclones exist in Bangladesh.

\section{a) Political factor}

Political factor has a direct link to vulnerability essentially because of the lack of decision-making power makes a community vulnerable in various ways. So, a deep-rooted socio-economic element, including- denial of human rights, denial of access to power structures, access to quality education, employment opportunities, land tenure, available of access to resources, access to infrastructure, basic services and information create and increase vulnerability, shaped by political factors.

Happily, political interfere is fundamental to disaster risk reduction. For instance- in 1994, South Africa's new democratic government decided to adapt and a new approach to the management of disaster and risks. This led to a total reform of the country's disaster risk management policy and legislation (Niekerk, 2011). Flood in 1974, hyperinflation, massive damage to infrastructure, institutional disruption and bloody political crisis turned Bangladesh into famine oddly in 1974-75 (Benson \& Clay, 2003). So, the political factor can make a vulnerable situation naturally to the cyclone.

\section{b) The physical vulnerability}

Physical vulnerability refers to susceptibilities to structural damage to buildings, vehicles, infrastructure, and lifelines (heat, food, water) and determined by population densely level; remoteness of a settlement; design and materials used for housing; difficulty in access to water resources, means of communications, hospitals, police stations, fire brigades, roads, bridges, etc. and the lack of proper planning and implementations in construction of residential and commercial buildings (Tapsell et al., 2013; Donner \& Rodriguez, 2011; ODPM, 2013).

Simultaneously, the district of the coastal area of Bangladesh is physically vulnerable for riverine floods, tropical cyclones, devasting storm surges, erosion, which have severe economic and social disruption and considerable loss of life (Benson \& Clay, 2003). For example- cyclone is a result of tropical monsoon climate, the nearest position from equator, worm oceanic temperature, presence high vertical wind, low-pressure areas in the Bay of Bengal and Chottogram, Cox's Bazar, Khulna, Noakhali are extremely vulnerable districts in Bangladesh having been located near the Bay of Bengal (Hossain et al., 2019; Hussain \& Rahman, 2018 ). Sidr in 2007 is a real example of it for which about 3406 people have died, 55,282 people were injured and a total of $\$ 1.67$ billion was damaged (Dasgupta et al., 2010).

The distinctive climate of Bangladesh has been affected rigidly by its location. Bangladesh is situated in the northeastern part of South Asia, about wholly bounded by the Indian border except for the South and south-east. 730 kilometers coastline is situated along the Bay of Bengal from the mouth of the Naf river on the Myanmar border to the mouth of the Raimangal river on the Indian border (Shamsuddin et al., 2015). Regrettably, on the other hand, there is the physical difference between rural and urban to raise vulnerability; for example- the inhabitant of the rural area is more vulnerable than the urban area. Because- lack of health service and hygienic toilets and natural disasters affect the rural area surely. Admittedly, the number of women in rural is more than urban areas and those women are dependent on men and family (Toufique \& Yunus, 2013). So, the number of families depending on women increases vulnerability in rural areas.

\section{c) Economic factor}

Economic vulnerability refers to income sources, including- the ease of access and control over means of production (farmland livestock, irrigation, and capital). To speak frankly, the level of vulnerability depends on the economy. Those individuals, communities and nations are poor who have less economy, shaped by different professional attributes, declining monthly average household income and savings, amount of monthly loan payment, damage of property and infrastructure, and food scarcity, etc. (ODPM, 2013; Hossain et al., 2019). 
Seemingly, the housing condition in Bangladesh is so bad, especially in coastal areas. A survey was carried out which proved that 46.67 percent house is kacha (housing with made mud, bamboo, and straw), 11.11 percent is Semi- Pucca (housing with foundation made of bricks and concrete, walls made of bamboo and wood, and roof made of tin), 20 percent house is Jhupri ( ceiling which is less than 4 feet, is made of cheap construction materials, bamboo, grass, leaves, polythene, etc.) and 22.22 percent is hut. Significantly, by force of the wind, those houses become damaged at the moment entirely. Simultaneously, people of coastal areas claim that they don't make resilient cyclone house because of weak socio-economic conditions (Siddeqa et al., 2018).

Lack of proper sanitation and pure drinking water, shaped by a lower economy, turn the coastal area of Bangladesh into vulnerability ostensibly. Research findings reveal that about 28.89 percent of people have a ring slab toilet, 33.33 percent of people have a hanging toilet and 37 percent of people have no toilet. On the other hand, 25 tube wells for 557 households, 37.50 percent people get pure drinking water, 38.63 percent of people get a little amount of pure drinking water and 23.87 percent of people don't get pure drinking water (Siddeqa et al., 2018).

Presumably, the lower household economic condition turns coastal areas into vulnerable people. A report has indicated that about 35.55 percent of people are in needy conditions, 44.44 percent of people are in temporary needy conditions, 13.33 percent of people are in income-expenditure equal condition and 6.67 percent people are rich (Siddeqa et al., 2018).

\section{d) Social factor}

Social vulnerability is often hidden, complex, and nested in various human aspects and influenced by variety of social factors- social class, income, education, lack of awareness, access to information and basic human rights, social equity, and strong cultural beliefs (Tapsell et al., 2013; Singh, 2014; Niekerk, 2011). Social vulnerability refers to inability of people, organizations and societies to reduce the impact of disaster due to characteristics inherent in social interactions, institutions, system of cultural values which are linked to the well-being of individuals and community, including- level of education, the existence of peace and security, access to basic human rights, system of good governance, social equity, positive traditional values, customs, and ideological beliefs, and political accountability (ODPM, 2013).

There are several reasons to increase social vulnerability, including- lack of access to education, disaster risk reduction, and climate adaptation information, knowledge and technology, limited access to political power and representation, and social capital (networks, connections, beliefs, and customs) (Singh, 2014; Cardona et al., 2012).

The above factors have influenced all dwellers, especially- children, women, very young, very old, orphans, nursing mothers, ethnic minorities, immigrant groups, and physically and mentally challenged people (Hossain et al., 2019; Niekerk, 2011).

\section{e) Cultural vulnerability}

Culture is related to life, behavior, taste, ethnicity, ethnic values, beliefs, customs, ideas, institutions, art, and intellectual achievement, which are produced and shaped by society. (Cardona et al., 2012). The dweller of coastal areas seems that cyclone doesn't destroy them and depend on God without trying to take a safe place. Most of the dwellers are Muslims and they obey the rules of Al-Quran. Al-Quran has declared to seek the way of life depending on Allah. But several people aren't agreed to change their attitude on disasters and accuse the luck; thus, they are vulnerable. So, they have to avoid depending on luck and search for a safe place. When searching for a safe place becomes a tradition all people will search for a safe place.

Children are socialized in uneducated culture, and most children are not agreed to go to school and other children are influenced by them to refuse to go to school. Refusing to go to school is a trend among children in coastal areas. A report has shown that primary school, high school, Caritas, head Bangladesh office are used to teach children, walking about one kilometer. About 41.45 percent of children don't go to school, 16.24 percent children don't go when they become injured, 26.22 percent children go to school willingly and 11 percent of children go to school in delay in coastal areas of Bangladesh (Siddeqa et al., 2018). When they go to school, they learn about the cyclone.

Going to cyclone shelter in the delay is a trend of those dwellers of coastal areas. Some people go cyclone shelters in delay, and other people learn from them going to shelter in delay.

\section{f) Geographical setting}


Climate change is unavoidable. It will stress people physically and economically in developing countries. Disasters are a complex mix of natural hazards and human action. Less developed countries are more vulnerable than in developed countries. The people of developing countries suffer repeated multiple, mutually reinforcing, and simultaneous shocks to their families, their settlements and their livelihoods (Wisner et al., 2003).

The vulnerability can be changed by rapid economic growth, urbanization, technical, and social changes. Bangladesh and the Caribbean have shown many testimonies of that by economic transformation and public actions (Benson \& Clay, 2003). Poverty is influencing developing countries which increases vulnerability in those countries. The insurance, savings, and investments or some other financial instruments help to reduce poverty (Niekerk, 2011). Developing countries, having huge social problems, are affected by the social vulnerability, including- lack of information, resource, even women, girls and the elderly are more vulnerable.

\section{g) Environmental factor}

The extent of natural resource depletion, the state of resource degradation, loss of resilience of the ecological system, loss of biodiversity, expose of toxic and hazardous pollutants are a key aspect of environmental vulnerability (ODPM, 2013; Niekerk, 2011). There are several environmental vulnerabilities in the coastal area of Bangladesh, Including- houses made of mud, with the straw roof, thatch roof, the house near the river, open sea and the Sundarbone, rurality or remoteness, road distance, distance from cyclone shelter and salinity prone area, etc. (Hossain et al., 2019). Open and bamboo-wooden structured latrines are common in rural areas that are damaged by the cyclone, and water bore diseases break out and sometimes spread out after the disaster of the cyclone (Rahman et al., 2018).

\section{h) Gender perspective}

Gender, a social difference between male and female, is a social factor of construction of disaster vulnerability and unequal distribution of disaster risk because women and men are differently at risk to disasters in all sets- at home, at work, in neighborhood in which gender shapes capabilities and resources of individuals to minimize harm and adapt to hazards and respond to disasters (Enarson \& Chakrabarti, 2009; Wailemacq \& McClear, 2017).

Cultural barriers; lack of girls' education, economic security and political participation and essential service; high level of poverty; higher fatality rate; slower recovery; the threat of displacement and high level of sexual violence and women related matters (the pregnancy, breastfeeding, menstruating, lack of underwear and sanitary materials) constrain women personal autonomy and physical mobilities (Niekerk, 2011; Rahman, 2013). A recent report has revealed that only 90 percent of women get warning of the cyclone, and only 41 percent of women go to cyclone shelter and others don't go because of distance from cyclone shelter, lack of access to road and cyclone shelter, slippery road, and stormy wind. Even they reach the shelter and shelters are more crowded; lack of proper ventilation, water supply, sanitation facilities, proper space, separate space and toilets for women and help for pregnant women; uncomfortable situation; staying with the unfamiliar male, and children start crying in bad weather (Shahjahan, 2018).

Generally, women in Bangladesh work at home; they don't get warning signals. When their son or husband comes home, women get news of cyclones. About two-thirds of women don't understand the measurement of a warning signal and about one-third of women understand a warning signal because of attending the training. As women get a warning signal, at last, they have too many tasks for going shelter, including- gathering livestock, poultry, dairy commodities, when the male partner is not present, women feel very pain. During the cyclone, some men go to Mosques and Madrasahs, but women can't go there because of cultural and religious prevention. Due to a lack of cyclone shelter, women can't go cyclone shelter. They take shelter at brick-built homes (Shahjahan, 2018). Women are subordinate to men in Bangladesh. About 90 percent of women live in rural areas and they have too many works, including- cooking, cleaning, washing, doing agricultural work, bearing and caring children (Nasreen, 2012). Last, of all, the main cause of women's vulnerability is lack of sustaining, participating, empowering in decision making power in disaster prevention, preparedness programs, and recovery operations (Rahman et al., 2018).

\subsection{Vulnerability mitigation}

In 1988, the Intergovernmental Panel on Climate Change (IPCC) was established jointly by the World Meteorological Organization (WMO) and the United Nations Environmental Programme (UNEP). This IPCC has focused on global warming and climate change; even it makes general people attentive about interest, awareness, 
concern, worries and weather events. The Government and NGOs have started their activities by inspiring of IPCC (Shamsuddin et al., 2015).

Disaster risk doesn't depend on the intensity of hazards and number of people, rather on vulnerable condition as well as comprehensive efforts can reduce vulnerability, including- implementing building codes, insurance, and social protection, emphasizing economic diversity and resilient livelihoods, knowledge and awareness-raising, and preparedness measure (PreventionWeb, 2015). For example,- some initiatives have played good impacts on reducing the cyclone-oriented mortality rate. Because 5,00,000 people died in 1970 and 4234 people died in 2007. Initiatives are- early warning systems, cyclone shelters, evacuation plans, coastal embankments, reforestation, schemes, increasing awareness and communication (Shahjahan, 2018). Besides Bangladesh Government, other people and organizations have to work to reduce vulnerability and damage rate. The author has identified four levels of activities for reducing vulnerability and developing those areas. Such as-

\section{a) Individual-level}

Siddeqa et al. (2018) argued some individual-level activities can help reduce vulnerability, such as- young generation can play a vital role to help others, male person can migrate to urban area for earning money, avoiding indigenous knowledge and using TV and radio, immediate preparation towards disasters (taking dry food, drinking water and candle) and learning from previous experience. People have a lack of making the exact decision because they don't get out from home when cyclone come very near, they get out. They seem that when they leave home, their property will be stolen. According to a study published recently, $37.78 \%$ of dwellers take shelter at Caritas and head Bangladesh office, $31.11 \%$ at school, $6.67 \%$ on the bridge, $6.67 \%$ on the road, $8.89 \%$ at the neighbor house, $8.89 \%$ at own house. On the other hand, most of the people in coastal areas are illiterate; they aren't aware of the preparedness of cyclones. Such as- up to 15 years children are left out from education and about 85 percent of children have no idea about cyclone warning and preparedness (Shahjahan, 2018).

To increase their awareness, training about preparedness must be ensured. When they get training, they will be aware of the consequences of the cyclone (Siddeqa et al., 2018).

\section{b) Community-level}

Young generations have a vital role in reducing vulnerability. The young generation has to make committees which conduct several activities, including- repairing embankments, cyclone shelter, and communication system, helping researchers in those regions to conduct research, distributing reliefs and other services and helping to send older and disabled people at the shelter, etc. Vulnerability due to lack of trees around the house is visual in coastal areas. Only rain trees and banana trees are seen in those coastal areas (Siddeqa et al., 2018).

As a tree can reduce the motion of the speedy wind, so planting a wind-resilient tree is obviously need. Young generations have to motivate to general people and plant wind-resilient trees around the house, embankment, road, and village along with they can make general people understand the bad impact of the weak and risky branch of the tree and motivate to cut them down before cyclone. Many female leading families can't maintain a crisis (Siddeqa et al., 2018). The young generation has a duty on those female-maintained family to send to cyclone shelter.

\section{c) National-level}

The Bangladesh Government has to ensure access to open water resources (sea, river, char land, Khas land, and forest). Beside rising financial capital (Mahajon, Arotder, Friends, relatives), worker of agriculture, health, family planning and fishery; Union Parishad; NGOs and physical resources (market center, village road, cyclone, shelter, tube-wells, hospital, school) can help reduce vulnerability and damage rate of cyclone (Paul, 2013). Furthermore, ensuring mike, siren and by-cycle, radio on $24 / 7$ basis, separate place at shelter for male and women, medical facility, even giving training to some women who will help ill women, arranging electricity in shelters, vulnerability mapping, location analysis, etc. must be ensured for getting suitable result of mitigating vulnerability (Shahjahan, 2018).

NGOs are the third executive arm of government. Government-NGOs conflict also prevents to reduce vulnerability. NGOs claimed that they are being prevented from conducting their activities properly and the government has dominated them to regard and approve the project (Nawaz, 2019). On the other hand, the Government claimed NGOs show more actions than works and are a threat to our sovereignty. But NGOs' help is must be needed to reduce vulnerability. So, Government has to be liberal with sustaining sovereignty of Bangladesh to NGOs to get 
relief. Also, the Bangladesh government has to search for help from international organizations and make them understand our demand to reduce vulnerability in coastal areas. People of rural areas are drinking water from ponds and canals. After cyclone safe drinking water becomes more needed, even the price of safe drinking water has risen. The Government and NGOs can install more tube-wells in rural areas (Toufique \& Yunus, 2013).

Finally, To reduce the damage of cyclone, Government has to take some steps, like- to increase cyclone preparedness (increasing invest in cyclone warning system, making new cyclone shelter, rising evacuation plan), the coastal management (coastal embankment, tree plantation, sustainable development in the coastal area) and postcyclone activity (relief operation, recovery, reconstruction on the affected areas) (Shamsuddin et al., 2015).

The authority has to see whether officials work or not and establish monitoring bodies, and policymakers have to make policies through field observation. The Federal Emergency Management Agency- The State and Local Guide101 (FEMA-SLG-101) has developed an Emergency Operation Plan Process based on fire in the USA (Kramer, 2009). The author has argued the process of FEMA-SLG-101 may be helpful after the cyclone in coastal areas of Bangladesh. Because there are many administrative problems after the cyclone so that this Emergency Operation Plan Process may be yielded. The process: Prepackaged plans may not be helpful; emergency activities must be helpful. Process-

1. Principles: making new plans and policies consumes huge time, as the authority has to work immediately, with regarding others' opinions in daunting tasks, they should revision previous plans and policies so that they can start the task as soon as possible.

2. Research: to commit tasks, some tasks can be conflicted with laws and regulations, and higher authority may prevent the tasks. So, planners have to make conjunction between laws and plans. Also. NGOs' help may be conflicted with state sovereignty. By helping through their agreement, they can take the secret information of Bangladesh. So, plan to be according to state laws.

3. Development:

Firstly, the authority has to identify and inform exact news of cyclone (the possible result of the cyclone, who and which property are at risk) and focus on the historical cyclone to investigate and collect data.

Secondly, seeking the resource of response agencies who help by giving money or commodities - even calling new agencies to give helping hand so that recovery can be possible easily.

Thirdly, reducing communicational barriers so that helping agencies can go fast.

Fourthly, to write a plan, they have to use this process: Making rough draft $\rightarrow$ distributing for review $\rightarrow$ incorporating a review.

4. Validation: planners have to ensure that all plans meet with the laws and regulations, test the plan via exercises to include-tabletop, functional, and full scale, and incorporate a review.

5. Maintenance: plan-oriented people or agencies have to work at a due time exactly, which reduces the rate of damage and recovery will be seen immediately.

\section{d) International-level}

According to geographical location, the vulnerability varies from country to country. Bangladesh is situated at a vulnerable location that is facing the impact of global warming risen by the developed countries. International organizations have to be attentive to the impact of global warming in Bangladesh and other developing countries. The International organization also has to give subsidy and budget for Bangladesh, which can reduce the vulnerability rate and call for help from Bangladesh.

\section{DISCUSSION OF FINDINGS}

It is easy to imagine how Bangladesh has been suffering from the crucial impacts of the cyclone, damaging huge people, property, infrastructure, environment, and social stability for many years because of geographical location, low economy, low coping capacity and unaware population. Vulnerable conditions, including- poverty, weak housing, and unawareness, raise the intensity of damaging the cyclone. Many research findings have shown that only women, girls, disabled people and elderly people are vulnerable people. This study has shown that those women, girls, disabled people and elderly people are vulnerable who have weak housing and unawareness. Even 
women in those low-income families are vulnerable, not overall women of those affected areas. A woman who has a strong building to live, but a man who has a weak hut, who is vulnerable? So, to be vulnerable, people have to be poor, unaware and weak housing but in this low-income family, a wife is more vulnerable than other members.

On the other hand, Bangladesh is also situated in a vulnerable position, capitalist countries raise carbon-dioxide and it affects the coastal countries all over the world, such as- Bangladesh. This study was conducted not because to identify vulnerability but because to identify mitigation of vulnerability. The fact that the vulnerability to the cyclone is high in Bangladesh proves that there is a lack of proper steps and policies and weak enforcement of policies. The last part of the analysis has identified that proper steps can reduce the damage rate of cyclones in Bangladesh. Last, of all, the author has argued that the Emergency Operations Plan Process may be helpful in the emergency after the cyclone.

\section{CONCLUSION}

Cyclone makes vulnerable the dweller in coastal areas and slows down the process of social and economic development (Shahjahan, 2018). Finally, we can say that to develop the coastal area of Bangladesh; some initiatives must be taken. As the coastal area of Bangladesh is poor, without developing those areas, Bangladesh won't be developed at all. Every year, cyclone, having more or fewer effects, occurs in Bangladesh. To develop those areas, reducing vulnerability must be ensured which helps to reduce damage rate obviously. Not only the Bangladesh Government, dwellers of those areas, national and international NGOs and institutions have to come forward to reduce vulnerability in Bangladesh which is crucial needed. People have to be aware of and take training in obeying the rules of training. The Government-NGOs conflict has prevented the motion of vulnerability reduction, so, Government Organizations have to compromise with NGOs and make the Government-NGOs collaboration which makes Bangladesh developed. Besides, all Universities of Bangladesh have to be attentive to the cyclone and its impact on Bangladesh, although several Universities have conducted research on the cyclone, especially- the University of Barishal, University of Dhaka, etc. and will conduct research in future. Thus, the vulnerability will be diminished and sustainable development goals will be visual in Bangladesh soon. It is only when everyone plays his or her role exactly that vulnerability can be eradicated from the coastal area of Bangladesh.

\section{LIMITATION AND STUDY FORWARD}

The author has found out descriptive findings based on secondary data and hasn't provided any statistical findings for generalizing. Only vulnerability to the cyclone has been analyzed among a lot of disasters in the coastal area of Bangladesh, also,

1. Primary data haven't been used,

2. Comparatively a few data have been used,

3. It is also unable for generalizing

At the eleventh hour, though this study has several limitations, it has made a pattern of vulnerability to the cyclone, which may help take action to reduce vulnerability.

\section{ACKNOWLEDGMENT}

I want to thank my teacher, named Md. Sadequr Rahman who has taught and inspired me to conduct this study. Then, I would like to acknowledge my friends who have inspired and helped me, named- Md. Muhimenul Islam, Md. Al Rakib, Nazmun Nahar Showmi, and Md. Parvez Hossain.

\section{REFERENCES}

Ahmed, A. K. (2017). U.S. Patent No. 9,645,992. Washington, DC: U.S. Patent and Trademark Office.

Alam, E., \& Collins, A.E. (2010). Cyclone disaster vulnerability and response experiences in coastal Bangladesh. Journal Compilation (C) Overseas Development Institute, 34(3), 932-45. Doi: 10.1111/j.03613666.2010.01176.

Benson, C. \& Clay, E. (2003). Economic and Financial Impacts of Natural Disasters: An Assessment of Their Effects and Options for Mitigation: Synthesis Report. Washington DC: World Bank. 
Bisson, T. (2012). An Assessment of Cyclone Mitigation and Management Policies of Bangladesh: A Focus on Early Warning Systems. Faculty of Environment, Earth and Resources. University of Manitoba. Retrieved from http://umanitoba.ca/institutes/natural_resources/pdf/TiffanyBissonFullThesisJan24.pdf

Cannon, T. (2008). Reducing People's Vulnerability to Natural Hazards: Communities and Resilience. Wider Research Paper 34, Helsinki: United Nations University.

Cannon, T. (2008). Vulnerability, "innocent" disasters and the imperative of cultural understanding. Disaster Prevention and Management. doi: 10.118/096535608108872275

Cardona, O.D., Aalst, M.K.V., Birkmann, J., Fordham, M., McGregor, G., Perez, R., Pulwarty, R.S., Schipper, E.L.F., \& Sinh, B.T. (2012). Determinants of Risk: Exposure and Vulnerability. In, Managing the Risks of Extreme Events and Disasters to advance Climate Change Adaptation. A special Report of Working Groups I and II of the Intergovernmental Panel on Climate Change (IPCC), pp.65-108, Cambridge University Press, Cambridge.

Chaudhury, M. (2017). Strategies for reducing vulnerability and building resilience to environmental and natural disasters in developing countries. United Nations Department of Economic and Social Affairs, Division of Social Policy and Development.

Dasgupta, S., Pandey, K., Haq, M., Khan, Z.H., Ahmed, M.M.Z., Mukherjee, N., \& Khan, M.F. (2010). Vulnerability of Bangladesh to Cyclones in a Changing Climate: Potential Damages and Adaptation cost. Policy Research working paper: no.WPS5280. World Bank, Retrieved from

Donner, W., \& Rodriguez, H. (2011). Disaster Risk and Vulnerability: The role and Impact of Population and Society. Population Reference Bureau. Retrieved from https://www.prb.org/disaster-risk/

Goosen, H., Hasan, T., Sah, S.K., Rezwana, N., Rahman, M.R., Assaduzzaman, M., Kabi,r A., Dubois, G., \& Scheltinga, C.T.V. (November, 2018). Nationwide Climate Vulnerability Assessment in Bangladesh. A joint publication of the ministry Environment, Forest and Climate Change, Government of the People's Republic of Bangladesh and GIZ.

Hossain, M.S., Karlson, M., \& Neset, T. (2019). APPLICATION OF GIS FOR CYCLONE VULNERABILITY ANALYSIS OF BANGLADESH. Earth Sciences Malaysia (ESMY) 3(1), 25-34. doi: http://doiorg/10.26480/esmy.012019.25.34

Hussain, K.T., \& Rahman, M.H. (2018). DELINEATING THE SERVICE AREA OF CYCLONE SHELTER AND VULNERABLE HOUSEHOLDS USING NETWORK ANALYST TOOL: BAGERHAT DISTRICT, BANGLADESH. J. Asiat. Soc. Bangladesh, sci. 44(2), 137-148.

International Federation of Red Cross and Red Crescent Societies (IFRCRCS), (2019). What is Vulnerability. https://www.ifrc.org/en/what-we-do/disaster-management/about-disasters/what-is-a-disaster/what-is vulnerability/

Khan, S.R. (1992), CYCLONE HAZARD IN BANGLADESH. Community Development Library, Dhaka.

Kramer, W.M. (2009). DISASTER PLANNING AND CONTROL, PennWell Corporation, USA.

Miyan, M.A. (2005). CYCLONE DISASTER MITIGATION IN BANGLADESH, Proceeding of the second Regional Technical Conference on Tropical Cyclones, Strom Surges and Floods. Secretariat of the World Metrological Organization. Geneva.

Nasreen, M. (2012). Women and Girls Vulnerability on Resilient?. Institute of Disaster Management and Vulnerability Studies, University of Dhaka, Bangladesh.

Nawaz, F. (2019). Government and NGO collaboration, The Daily Star. retrieved from https://www.thedailystar.net/news-detail-93849.

Niekerk, D. V. (2011). INTRODUCTION TO DISASTER RISK REDUCTION. United States Agencies for International Development report. Retrieved from https://www.preventionweb.net/files/26081 kplconcepdisasterrisk1.pdf

OFFICE OF DISASTER PREPAREDNESS AND MANAGEMENT (ODPM) (2013): A Division the Ministry of National Security. Vulnerability and Risk. Retrieved from http://www.odpm.gov.tt/node/162

Paul, S.K. (2013). Post-Cyclone livelihood status and strategies in coastal Bangladesh. Rajshahi University journal of life \& earth and agricultural sciences, 41, 1-20. doi: https://doi.org/103329/rujleas.v41i0.21623.

PreventionWeb: The knowledge platform for disaster risk reduction. (2015). Disaster Risk- Vulnerability. Retrieved from https://www.preventionweb.net/risk/vulnerability

Rahman, M.S. (2013). Climate Change, Disaster and Gender Vulnerability: A Study on Two Divisions of Bangladesh. American Journal of Human Ecology, 2(2), 72-82. doi: 10.11634/216796221302315

Rahman, M.S., Gonzalez, P.A., \& Delgado, R.C. (2018). Exploring Socio-Economic Vulnerability of Disadvantaged People in Bangladesh: The Context of Cyclone and Tidal Surge. Barishal University Journal P1. 5 (1), $27-$ 45. 
Shahjahan, M. (2018). Assessing The Cyclone Early Warning Services Of Women, Children And Person With Disability: A Case Study In Nijhumdwip. Brac University Institutional Repository, Dhaka, Bangladesh. http://Dspace.Bracu.Ac.Bd/Xmlui/Handle/10361/10214

Shamsuddin, S.D., Ahmed, R., \& Jahan, R. (2015). CLIMATE VARIABILITY: Issues and perspectives for Bangladesh. Sahitya Prokash, Dhaka, Bangladesh.

Shamsuddoha, M., \& Chowdhury, R. K. (November, 2007). CLIMATE CHANGING IMPACT AND DISASTER VULNERABILITIES IN THE COASTAL AREAS OF BANGLADESH. COADT Trust and EJWG publication, Dhaka, Bangladesh.

Sharmin, Z., \& Islam, M.S. (2013). Consequences of Climate Change and Gender Vulnerability: Bangladesh Perspective. Bangladesh Development Research Working Paper Series (BDRWDPS) 16.

Siddeqa, M., Islam, M.T., Shahin, M., \& Biswas, A.A. (2018). Cyclone vulnerability and coping strategies of coastal community: village level assessment in Bangladesh. Discovery Publication, 54, 213220. Retrieved from http://www.pstu.ac.bd/files/publications/1532958996.pdf

Singh, S.R., Eghdami, M.R., \& Singh, S. (2014). The Concept of Social Vulnerability: A Review from Disasters Perspectives. International Journal of Interdisciplinary and Multidisciplinary Studies (IJMS), 1(6), 71-82. Retrieved from

Tapsell, S., McCarthy, S., Faulkner, S., \& Alexander, M. (2012). Social vulnerability to natural hazards. Flood Hazard Research Centre (FHRC), Middlesex University.

Toufique, K.A., \& Yunus, M. (2013). Vulnerability of Livelihoods in the Coastal Districts of Bangladesh. Bangladesh Development Studies, Bangladesh Institution of the Development Studies, 36(I), 95-120.

Wailemacq, P., \& McClear, D. (2017). Economic Losses, Poverty and Disaster 1998-2017. United Nations office Disaster Risk Reduction (UNISDR) \& Centre for Research on the Epidemiology of Disaster (CRED) https://www.unisdr.org/files/61119_credeconomiclosses.pdf

Wisner, B., Blaikie, P., Cannon, T., \& Davis, I. (2003). At Risk: natural hazards, people vulnerability and disasters ( $2^{\text {nd }}$ edition). Routledge publication, London. 